\title{
Residents' support for tourism development: The role of residents' place image and perceived tourism impacts
}

\author{
Dimitrios Stylidis $^{\mathrm{a}^{*}}$, Avital Biran $^{\mathrm{b}}$, Jason Sit $^{\mathrm{b}}$, Edith M. Szivas ${ }^{\mathrm{c}}$
}

a Ben-Gurion University of the Negev, Eilat Campus, Department of Hotel and Tourism Management, Israel

b Bournemouth University, School of Tourism, UK

c SeaStar Consultancy, United Arab Emirates

* Corresponding author

\begin{abstract}
Drawing on the triple bottom line approach for tourism impacts (economic, sociocultural and environmental) and adopting a non-forced approach for measuring residents' perception of these impacts, this study explores the role of residents' place image in shaping their support for tourism development. The tested model proposes that residents' place image affects their perceptions of tourism impacts and in turn their support for tourism development. The results stress the need for a more flexible and resident-oriented measurement of tourism impacts, revealing that more favorable perceptions of the economic, socio-cultural and environmental impacts lead to greater support. Moreover, while residents' place image has been largely neglected by tourism development studies, the findings of this study reveal its significance in shaping residents' perception of tourism impacts as well as their level of support. The practical implications of the findings for tourism planning and development are also discussed.
\end{abstract}

Keywords: Residents' place image, destination image, support for tourism development, tourism impacts, sustainable development.

\section{Introduction}

Tourism development renders various economic, socio-cultural and environmental changes on the host community's life, some more beneficial than others (Lee, 2013). Thus, the participation and support of local residents is imperative for the sustainability of the tourism industry at any destination (Gursoy, Chi \& Dyer, 2010). Understanding the residents' perspective can facilitate policies which minimize the potential negative impacts of tourism development and maximize its benefits, leading to community development and greater support for tourism (Prayag, Hosany, Nunkoo \& Alders, 2013). A rich body of literature investigates the relationships between residents' perceived impacts of tourism and their support for tourism development (e.g., Gursoy et al., 2010; Ko \& Stewart, 2002; Nunkoo \& 
Ramkissoon, 2012). Yet, most of these studies adopt an a priori categorization of potential impacts (into positive or negative economic, social-cultural and environmental impacts or simply costs and benefits), whereas limited attention is given to the residents' own evaluation of the extent to which they perceive an impact as being positive or negative (Andereck, Valentine, Knopf \& Vogt, 2005).

Additionally, recognizing the uniqueness of destinations, much attention has been given to the role of place attachment in shaping residents' perceived impacts and support for tourism development (e.g., Gursoy \& Rutherford, 2004; Lee, 2013). Another factor relevant to the understanding of residents' reaction to tourism is place image. Despite the importance assigned to place image in understanding tourists' attitudes and behavior in the tourism literature (Chen \& Tsai, 2007; Gallarza, Saura \& García, 2002), only a few studies have explored the image that residents hold of their place and even fewer have investigated its influence on their attitudes and reaction to tourism development (Ramkissoon \& Nunkoo, 2011; Schroeder, 1996). If tourism development is to benefit the local community, attention should also be given to the residents' image of the place rather than that of tourists' only. Moreover, place attachment is a rather stable psychological trait (Govers, Go \& Kumar, 2007) whereas image is a dynamic construct built upon the perceived place attributes, which may change and evolve with time. As such, image may be more suitable to capturing residents' reaction toward the changes to the place inflicted by tourism development.

To address the aforementioned research gaps, this study draws on the triple bottom line approach of perceived impacts (economic, socio-cultural and environmental) and adopts a non-forced approach (Ap \& Crompton, 1998; Jurowski, Uysal \& Williams, 1997) to their measurement. The non-forced approach aims to provide a more nuanced and accurate reflection of the residents' perceptions of tourism impacts. In addition, this study investigates whether residents' image of their own place influences their perceptions of the economic, socio-cultural and environmental impacts of tourism, and support for further tourism development. As part of this, environmental psychology studies and place image literature were used to achieve a more comprehensive reflection of residents' place image, and its relationships with their support for tourism development.

\section{Residents' support for tourism development}

Since the goodwill and cooperation of the local community is essential for the success and sustainability of any tourism development project, the understanding of residents' views and the solicitation of such support is of great importance for local government, policy makers and businesses (Dyer, Gursoy, Sharma \& Carter, 2007; Lee, 2013; Nunkoo \& Gursoy, 2012). Indeed, this has been a subject for on-going research in tourism (Gursoy, Jurowski \& Uysal, 2002; Nunkoo \& Ramkissoon, 2012). Early studies have been criticized for being descriptive, offering no explanation as to why residents perceive and respond to tourism as they do (Gursoy \& Rutherford, 2004). To provide a more insightful explanation of the factors shaping residents' support, later studies adopted various theoretical frameworks, such as 
Fishbein and Ajzen's (1975) Theory of Reasoned Action (e.g., Dyer et al., 2007) and Social Representation Theory (e.g., Andriotis \& Vaughan, 2003).

Social Exchange Theory (SET) has been the most commonly accepted framework in explaining residents' reaction to tourism development, since it allows for the capturing of differing views based on experiential and psychological outcomes (Nunkoo \& Ramkissoon, 2011; Prayag et al., 2013). SET considers social interactions as an exchange of resources, suggesting that individuals are likely to engage in an exchange if they expect to gain benefits from it without incurring unacceptable costs (Ap, 1992). In relation to tourism, residents' attitude is built upon their evaluation of tourism "in terms of expected benefits or costs obtained in return for the services they supply" (Ap, 1992, p.669). If the perceived positive impacts (benefits) outweigh the potential negative consequences (costs), residents are likely to support tourism development (Dyer et al., 2007; Gursoy et al., 2010; Ko \& Stewart, 2002; Lee, 2013). As such, residents' perceptions of the impacts of tourism are an important consideration for successful development and operation of tourism (Andriotis \& Vaughan, 2003; McGehee \& Andereck, 2004).

\subsection{Residents' perception of tourism impacts}

Past studies suggest that the three main elements involved in the exchange process of tourism development are economic, socio-cultural and environmental impacts (e.g., Jurowski \& Gursoy, 2004; Nunkoo \& Ramkissoon, 2012; Vargas-Sánchez, Plaza-Mejía \& PorrasBeeno, 2009). This is also in line with the triple bottom line approach to impacts, commonly used in sustainable tourism development literature (Andersson \& Lundberg, 2013; Prayag et al., 2013). Additionally, it is recognized that tourism has the potential for both favorable and unfavorable impacts on the local community with regard to each of these exchange domains (Andriotis \& Vaughan, 2003; Prayag et al., 2013). For instance, tourism may increase employment opportunities and improve standards of living, but may increase the cost of living (Ko \& Stewart, 2002; Nunkoo \& Ramkissoon, 2012; Upchurch \& Teivane, 2000). Tourism development enhances cultural exchange and provision of recreational opportunities, but can lead to increased crime rates (Ap \& Crompton, 1998; Dyer et al., 2007). Often tourism is considered responsible for environmental pollution, noise and congestion (Latkova \& Vogt, 2012; Nunkoo \& Ramkissoon, 2010). However, it may also have positive environmental impacts by improving the area's appearance and enhancing natural and cultural protection (Ko \& Stewart, 2002; Vargas-Sánchez et al., 2009).

Drawing on SET, numerous studies have verified the significance of residents' perception of tourism impacts in influencing their support for tourism development (e.g., Nunkoo \& Ramkissoon, 2011; 2012). Yet, there is a lack of agreement in the literature regarding the classification and measurement of residents' perception of impacts. A review of the literature reveals three main approaches, which have been adopted in previous studies. These can be termed as the costs-benefits approach, domain related costs-benefits approach and the non-forced approach (see Table 1). The first and the most prevalent approach is the 
costs-benefits approach (Nunkoo \& Ramkissoon, 2011; Lee, 2013). Studies following this approach group the potential impacts of tourism into two dimensions of costs and benefits (or positive/negative impacts), generally indicating a direct negative relationship between perceived costs and support for tourism development and a direct positive relationship between perceived benefits and support (e.g., Lee, 2013; Nunkoo \& Ramkissoon, 2011; Nunkoo \& Gursoy, 2012). While this approach is uncomplicated and straightforward, it overlooks the impacts of tourism on the diverse aspects of community life (i.e., economic, socio-cultural and environmental). Therefore, it provides only a partial understanding of the ways in which perceived impacts influence residents' support, which may hinder the predictive strength of the structural model (Gursoy et al., 2010; Nunkoo \& Ramkissoon, 2012) and is less insightful for sustainable development and the marketing of new projects (Prayag et al., 2013).

Studies adopting the domain related costs-benefits approach aim to provide a more comprehensive understanding of the relationships between perceived impacts and residents' support by considering both the nature (positive/negative or cost/benefit) and domain (economic, socio-cultural, environmental) of impacts. Here, studies have delineated impacts into several areas of perceived positive and negative environmental, social/cultural and economic impacts. For instance, Gursoy and Rutherford (2004) examined the influence of economic benefits, social benefits, social costs, cultural benefits and cultural costs on residents' support (see also Dyer et al., 2007; Gursoy et al., 2010). More recent studies explored six areas of negative and positive economic, socio-cultural and environmental impacts (Prayag et al., 2013). Similar to the costs-benefits approach, the domain related costsbenefits approach hypothesizes direct positive relationships between the economic, sociocultural and environmental benefits and support, and direct negative relationships between the economic, socio-cultural and environmental costs and residents' support (Dyer et al., 2007; Gursoy \& Rutherford, 2004; Gursoy et al., 2010).

\section{[Table 1]}

The domain related costs-benefits approach stresses the need to consider not only the nature of impacts (i.e., costs/benefits) but also the domain of impacts to gain a better understanding of residents' reaction to tourism. As such, this approach reflects the compromise between the diverse domains of positive and negative impacts of tourism development that residents of a particular destination are willing to make (Andereck et al., 2005; Dyer et al., 2007) and explains a greater portion of the variance of residents' support (Gursoy \& Rutherford, 2004). For example, studying communities during economic downturn, Gursoy and Rutherford (2004) reveal that residents place greater importance on the economic benefits of tourism, rather than the perceived social and cultural impacts, which had no significant effect of residents' support. Similarly, Gursoy et al. (2010) focused on alternative tourism development in coastal areas, and revealed that residents place higher importance on the potential economic and cultural benefits of such development, while 
Please reference as: Stylidis, D., Biran, A., Sit, J., \& Szivas, E. M. (2014). Residents' support for tourism development: The role of residents' place image and perceived tourism impacts. Tourism Management, 45(0), 260-274. doi: http://dx.doi.org/10.1016/j.tourman.2014.05.006

perceived social benefits and socio-economic costs were insignificant in shaping their support.

Yet, studies adopting the costs-benefits and the domain related costs-benefits approaches rely on an a priori categorization of the impacts (into positive or negative economic, social-cultural or environmental impacts or simply costs and benefits). In both approaches, respondents are not given the autonomy or opportunity to indicate the extent to which they perceive an impact as being positive or negative, but are confined to stating their level of agreement with pre-coded positive or negative statements (Andereck et al., 2005; Ap \& Crompton, 1998). For example, tourism "creates employment opportunities", "creates more business for local people" or "increases the prices of goods and services" (Gursoy \& Rutherford, 2004; Ko \& Stewart, 2002; Nunkoo \& Ramkissoon, 2011). Such measurement reflects the researchers' evaluation of the directionality of the potential impacts rather than the residents' own viewpoint (Andereck et al., 2005; Ap \& Crompton, 1998). Ap and Crompton (1998), for instance, illustrate that it cannot be assumed that agreement with the idea that "tourism creates more jobs" means the respondent sees this change favorably, as the jobs created may be lowly paid, seasonal and menial. This is supported by empirical findings, indicating residents' belief that tourism creates more jobs for foreigners and which are lowly paid (e.g., Akis, Peristianis \& Warner, 1996; Iroegbu \& Chen, 2001).

To overcome the limitations of the costs-benefits approach and the domain related costs-benefits approach, other studies have opted for a non-forced approach in measuring impacts. In this context, residents are provided with a series of neutrally phrased statements, asking for their own perceptions of directionality, namely the extent to which they consider tourism to have a positive or negative effect on the various domains of community life (Andereck et al., 2005; Ap \& Crompton, 1998; Deccio \& Baloglu, 2002; Jurowski et al., 1997; Upchurch \& Teivane, 2000). Studies adopting this approach present several classifications of perceived impacts. Deccio and Baloglu (2002) grouped the range of impacts into "opportunities" and "concerns" (equivalent to positive/negative impacts) and suggest that both have a direct positive relationship with residents' support for mega-events. Emphasizing the need to consider the interplay between the different domains of "exchange", Jurowski et al. (1997) classified impacts into perceived economic, social and environmental. They suggest direct positive relationships between all three types of impacts and residents' support for nature-based tourism development.

The studies drawing on the non-forced approach indicate that the more favorably or positively residents perceive the various impacts of tourism, the more likely they are to display greater support for tourism development. Alternatively, if tourism is perceived to have less favorable impacts (i.e., harming the economic, socio-cultural and environmental state of the community), residents are less likely to support further development. In contrast to the two previously mentioned approaches, which predetermine the nature of impacts (positive/negative), the non-forced approach suggests direct positive relationships between all domains of impacts and support. In this case, the perceived nature of the impacts (extent of 
Please reference as: Stylidis, D., Biran, A., Sit, J., \& Szivas, E. M. (2014). Residents' support for tourism development: The role of residents' place image and perceived tourism impacts. Tourism Management, 45(0), 260-274. doi: http://dx.doi.org/10.1016/j.tourman.2014.05.006

positive/negative perception) is reflected in the overall score of each impact (mean scores higher/lower than the midpoint of the scale indicate more positive/negative perception, see Deccio \& Baloglu, 2002).

Aiming to overcome the predisposition in the measurement of perceived impacts evident in the costs-benefits and domain related costs-benefits approaches, this study favors the non-forced approach which enables people to express their own perception of a tourism impact as positive or negative more freely. This study also draws on the SET and the common agreement that to understand residents' evaluation of the exchange made, and to enhance theoretical development, there is a need to consider the importance of each impact domain (Jurowski et al., 1997; Prayag et al., 2013). Therefore, it is hypothesized that when local residents express more positive (or less positive) perceptions of the impacts associated with tourism development, they will be more (or less) supportive of it. More specifically:

H1: There is a direct positive relationship between the perceived economic impacts of tourism and residents' support for tourism development.

H2: There is a direct positive relationship between the perceived socio-cultural impacts of tourism and residents' support for tourism development.

H3: There is a direct positive relationship between the perceived environmental impacts of tourism and residents' support for tourism development.

Recognizing that residents are heterogenous in their reaction to tourism development, past studies have extended the SET framework to incorporate other determinants that influence residents' support; for example, the state of the local economy, residents' economic gain, ecocentric and environmental attitudes and the use of tourism resources (e.g., Gursoy et al., 2010; Jurowski \& Gursoy, 2004; Nunkoo \& Ramkissoon, 2011). Since issues of sustainable development vary from one place to the other, the need for place specific policies, which recognize the particular context of the destination, was also highlighted (Nunkoo \& Ramkissoon, 2011; Teye, Sönmez \& Sirakaya, 2002). In this context, much attention has been given to the role of place attachment (or related terms such as, community attachment, place satisfaction and place identity (see Cui \& Ryan, 2011; Hernandez, Hidalgo, Salazar-Laplacea \& Hess, 2007; Lewicka, 2011) in shaping residents' perception of impacts and their support for development (e.g., Choi \& Murray, 2010; Gursoy \& Rutherford, 2004; Lee, 2013).

The concept of place attachment originates from Interpersonal Attachment Theory (Bowlby, 1969), which refers to the psychological and emotional bonds formed between an individual and another person. Similarly, place attachment is generally defined as a psychological characteristic of the individual, reflecting his/her emotive bond to a place (Cui \& Ryan, 2011; Hidalgo \& Hernández, 2001; Raymond, Brown \& Weber, 2010). Attachment is considered as a relatively stable individual's trait which is deeply evolutionary and biologically rooted (Bowlby, 1979). This notion is supported by empirical studies, indicating that individual differences in attachment are stable across one's lifespan (Waters, Merrick, Treboux, Crowell \& Albersheim, 2000). While tourism development studies have highlighted 
the importance of place attachment, due to the psychological and stable nature of attachment, this factor may offer only a partial understanding of the residents' perception of the changes to the characteristics of the place (i.e., economic, socio-cultural and environmental) and their support for tourism. It is suggested that another factor which may provide further understanding of residents' support, and which has been overlooked thus far, is that of residents' place image.

\subsection{Residents' place image}

The significance of place image in influencing people's attitude and behavior has been established in environmental psychology (e.g., Lynch, 1960), geography (e.g., Bolton, 1992; Kearsley, 1990) as well as place and product marketing (Ashworth \& Voogd, 1990; Elliot, Papadopoulos \& Kim, 2011). In the tourism literature, this notion is commonly examined under the term "destination image" with a proliferation of studies exploring its influence on tourist behavior and destination selection (Gallarza et al., 2002; Tasci \& Gartner, 2007). Generally defined as the sum of beliefs, ideas and impressions people hold of a place (Crompton, 1979; Kotler, Haider \& Rein, 1993), place image is a mental construct based on a few impressions chosen from the flood of information about a place (Echtner \& Ritchie, 2003; Kotler et al., 1993). As such, the majority of studies conceptualize place image in terms of the individual's perception of the specific attributes of the place, for example scenery, nightlife, etc. (Echtner \& Ritchie, 2003; Elliot et al., 2011; Gallarza et al., 2002). Residents' place image, therefore, is another key factor in understanding the formation of support for tourism development, one which is focused on the unique characteristics of the place rather than the individual's psychological involvement with the place. Moreover, while attachment is stable and less prone to change, image is a dynamic construct that changes as the place evolves (Govers et al., 2007; Tasci \& Gartner, 2007). As such, it might be more appropriate for capturing residents' perception of the impacts and changes to the place inflicted by tourism.

So far, limited attention has been given to the notion of residents' place image, especially in relation to its effect on residents' perception of tourism impacts and support for its development, with only two studies addressing this issue (Ramkissoon \& Nunkoo, 2011; Schroeder, 1996). This is surprising as tourism development typically involves a conscious attempt to enhance or change the image of a place and make it more attractive to both external and internal audiences (Bramwell \& Rawding, 1996; Reiser \& Crispin, 2009). This research gap can be attributed to the dominant focus of tourism literature on images held by tourists, namely aiming to satisfy external, non-resident, stakeholders as they are important revenue providers for the destination (Bigné, Sánchez \& Sanz, 2005; Ramkissoon \& Nunkoo, 2011). The need to consider residents' place image can be further understood in light of their "active" and "passive" role, as noted in previous image studies. 
Residents' active role refers to the idea that residents of a destination have their own images of the place they live in, which can be compared to those of tourists (Gallarza et al., 2002). The few studies adopting this line of thought stress that residents have a more comprehensive understanding of the place's attributes and uniqueness as well as the problems and changes inflicted by development (Henkel, Henkel, Agrusa, Agrusa \& Tanner, 2006; Jutla, 2000; Reiser \& Crispin, 2009; Ryan \& Cave, 2005; Sternquist-Witter, 1985). Hence, understanding the residents' perspective is important in identifying development trajectories that could bridge conflicting demands and images of the different stakeholders (Bandyopadyay \& Morrais, 2005; Dredge, 2010). Furthermore, residents also act as "tourists" in their own place, making use of recreational and tourism facilities (Bigné et al., 2005; Hsu, Wolfe \& Kang, 2004; Leisen, 2001), and can provide valuable insights for tourism development and marketing.

Following the common tendency of image research in tourism, residents' active role studies have focused on the place's function as a tourism and recreation setting, exploring domestic tourists within their own region/country (e.g., Hsu et al., 2004) or seeking residents' perception of tourism related attributes (e.g., Henkel et al., 2006). Attributes captured in such studies are similar to those common in tourists' destination image research, including scenery, cultural/historic attractions, nightlife and entertainment, shopping facilities and gastronomy (Echtner \& Ritchie, 2003; Gallarza et al., 2002). This approach overlooks the multifunctional nature of the place for residents as their "daily lifeworlds" (Green, 2005, p.37), i.e. not only as a recreational setting but also as a place to live and work. The need for residents' image studies to capture the various ways residents interact and view their place is further supported by studies of city image and place branding. Merrilees, Miller and Herington (2009), for example, refer to attributes such as nature, shopping and cultural activities alongside public transport, business and employment opportunities and government services. Consideration of the diverse "ingredients" constructing residents' image is important for facilitating developments which will sustain the place's valuable characteristics and address its negative aspects.

Residents' passive role in image studies has been brought about by the growing interest in understanding their attitudes toward tourism (Gallarza et al., 2002). This notion is reflected in the frequent consideration of residents as part of the image attributes of a destination, namely residents' friendliness or receptiveness (Echtner \& Ritchie, 2003; Elliot et al., 2011). Accordingly, residents' attitudes and support for tourism can influence tourists' perception of the destination (Gallarza et al., 2002). The few available studies suggest the importance of residents' image of their own place in shaping their perception of tourism impacts and support. In the context of marketing, Bandyopadyay and Morrais (2005) note that a dissonance between the external representation of the destination and the place image held by the local community can lead to resentment toward the tourism industry. Bramwell and Rawding (1996) further suggest that residents may be dissatisfied with developments which 
promote "standardized placeless images" (p. 203), whereas they are more likely to support development efforts which promote the distinctiveness of the place and its local inhabitants.

Schroeder (1996) provides empirical evidence indicating that residents' place image is associated with their support for tourism. Specifically, Schroeder (1996) compared between residents holding more or less positive image of North Dakota as a tourist destination (i.e., those having most-positive, average and least-positive image) in terms of their level of political support for tourism development and travel behavior. His findings indicate that residents who hold a more positive image display greater disposition towards state funding for tourism development, are more likely to recommend North Dakota as a place to visit, and engage in more trips within the area, as opposed to those holding a less positive image of the place. Other studies have also suggested that positive images held by residents are accompanied by positive word-of-mouth (e.g., Hsu et al., 2004; Leisen, 2001), indirectly displaying their support for tourism. These findings indicate that residents' image of their area may shape the organic image that non-residents have of the place (through information provided by locals) as well as directly influencing residents' support for tourism development. Following from this discussion, it is suggested that:

H4: There is a direct positive relationship between residents' place image and their support for tourism development.

It should be noted that similar to most image studies in tourism, Schroeder (1996) too has focused on the place's function as a leisure and recreational setting, exploring residents' perception of tourism-related place attributes such as friendly local people, accommodation prices, city sightseeing. Such conceptualization of image is incomplete as it overlooks the fact that the place also functions as the everyday life and work environment for residents. More importantly, although Schroeder (1996) provided evidence for the association between residents' place image and their support by comparing between groups of residents (using ANOVA), he did not examine the structural relationship of these two constructs. Finally, Schroeder (1996) overlooks the fact that residents' support is also shaped by their perception of tourism impacts, and thus image may also have an indirect effect on residents' support for tourism development, by shaping their views of tourism impacts.

Recognizing the importance of perceived tourism impacts and the need to establish a better understanding of the manner image affects residents' support, Ramkissoon and Nunkoo (2011) investigated the structural relationships between residents' place image, their attitudes toward (overall) tourism impacts and support for (urban) tourism development. Their findings indicate that the more positive residents' image of the place is, the more likely they are to perceive the impacts of tourism favorably. This is also supported by studies in environmental psychology and urban planning, suggesting that residents' perception of their place affects their evaluation of the impacts of development projects (e.g., Devine-Wright \& Howes, 2010; Green, 2005). As such, it is suggested that residents' place image also has an indirect effect on support, as it shapes residents' perception of the impacts of tourism. Nonetheless, 
Ramkissoon and Nunkoo's (2011) model has a key limitation, in that it offers only a partial understanding of the relationships between residents' place image and their support for development. While their model explores the effect of different dimensions of place image (social, transport, government services and shopping attributes) on the perceived tourism impacts, it is lacking in terms of the conceptualization of perceived impacts. Specifically, Ramkissoon and Nunkoo (2011) note that their model considers perceived tourism impacts as a single construct of "overall tourism impacts". As such, their model ignores the common agreement (e.g., Prayag et al., 2013) on the multi-dimensional nature of tourism impacts (comprised of economic, socio-cultural and environmental impacts). Aiming to provide a deeper theoretical and practical understanding of the role of residents' place image in shaping their support, the current study proposes a model which integrates the various dimensions of perceived impacts and examines the structural relationships between residents' place image and the perceived economic, socio-cultural and environmental impacts. It is hypothesized that the more (or less) favorable is residents' image of the place, the more (or less) positively they will evaluate the impacts of tourism. More specifically:

H5: There is a direct positive relationship between residents' place image and their perceived economic impacts of tourism.

H6: There is a direct positive relationship between residents' place image and their perceived socio-cultural impacts of tourism.

H7: There is a direct positive relationship between residents' place image and their perceived environmental impacts of tourism.

Similar to Schroeder (1996), Ramkissoon and Nunkoo's (2011) measurement of residents' place image is also incomplete, as their image attributes primarily focus on the role of the place as residents' "daily lifeworlds" and overlook its role as a tourism and recreational setting, which is included in the current investigation. This has also been noted by Ramkissoon and Nunkoo (2011), suggesting that a "more rigorous testing of the model with additional city image attributes is needed" (p.137) to increase the predictive power of the model in explaining how residents' place image contributes to shaping their responses to tourism. Additionally, Ramkissoon and Nunkoo (2011) explored only the indirect effect of residents' place image on their support (through its effect on the perceived tourism impacts), neglecting the possibility that residents' place image may also directly shape their support for tourism development. Alternatively, the current study examines both the direct and indirect relationships between residents' place image on their level of support.

In summary, within the limited research into residents' place image only a handful of studies have examined its effect on their support for tourism development. These few studies are yet to provide a full understanding of the structural relationships between residents' place image, perceived tourism impacts and support for tourism development. Namely, one which considers both the direct and indirect effects of residents' place image on support as well as the range of potential tourism impacts. Additionally, past studies draw on a limited residents' place image construct, which does not reflect the multifunctional nature of the place for its 
residents. To address these gaps, the proposed model (Figure 1) suggests that residents' place image influences their perception of the economic, socio-cultural and environmental impacts of tourism, which in turn affect their level of support for tourism development. It is suggested that residents' place image also has a direct effect on the ultimate dependent variable: residents' support for tourism development. In doing so, this study also provides a more comprehensive measurement of residents' place image.

[Figure 1]

\section{Research methods}

\subsection{Study location}

Kavala (Greece) was chosen as the focus of this study. This was due to the fact that while an effective management of residents' perception of tourism impacts and solicitation of their support are imperative in the early stages of development, there is a lack of research on urban destinations in the early development stage (Vargas-Sánchez et al., 2009). Kavala (population 55,325) has a rich history that dates back to the $7^{\text {th }}$ century B.C. It is considered as the starting point of Christianity in Europe as this is where the first Christian European was baptized (Lydia). Moreover, the ruins of the ancient city and the theatre of Philippi constitute important national and international heritage monuments. The local economy is based mainly on the extraction and export of natural resources (e.g., oil, fishing, marble, agriculture) and more recently, a growing tourism industry (Chionis, 2005). Tourist nights reached 242,325 in 2010, with the main markets being UK, Germany and Bulgaria (Hellenic Statistical Authority, 2012). The city offers various tourism activities, from beaches and thermal baths to cultural festivals, World Heritage Sites and religious tourism. Future development plans involve the conservation of the old town district, and the building of a new marine and a beach resort.

\subsection{Sampling and data collection}

The target population consisted of permanent residents of Kavala (residing for more than one year) who are 18 years old or older. A sample size of at least 300 respondents was targeted in line with the requirements of Structural Equation Modeling (SEM), which is the main data analysis technique in this study (Hair, Black, Babin \& Anderson, 2010; Kline, 2010). To achieve this sample size, a multi-stage sampling strategy was applied. First, street names were clustered geographically according to their postcodes (based on a list available at the Greek Post Office), as each postcode represents one of the five districts of the city. Stratified random sampling was used to achieve a balanced representation of residents across the five districts (Graziano \& Raulin, 2004). Second, within each district, streets were randomly sampled using the street directory. Based on house numbers, households were then randomly approached and invited to take part in the study. Whilst this procedure is helpful in 
achieving a representative sample (Selvanathan, Selvanathan, Keller, Warrack \& Bartel, 1994), non-response bias may limit the generalizability of the findings (Dyer et al., 2007; Nunkoo \& Ramkissoon, 2012).

Data were collected during October-November 2009 using a structured selfadministered questionnaire that was hand-delivered by one of the authors to 650 households. The interviewer provided a brief explanation of the study to the person answering the door and invited them to participate in the study (if the person answering the door was below 18, the interviewer asked for an adult). If they were willing to participate, the interviewer waited on-site for the respondent to complete the questionnaire (10-15 minutes). This method, as opposed to drop off/pick up method, has the potential to achieve higher response rate (Czaja $\&$ Blair, 2005). To minimize possible bias due to interviewer-participant interaction, it was communicated to participants that their partaking is voluntary and anonymous and they were encouraged to state their own personal opinion as truthfully as possible (Podsakoff, MacKenzie, Lee \& Podsakoff, 2003). Only one person in each household was invited to participate, as people from the same household often hold similar views (Andriotis, 2005). The response rate was $77 \%$ (500 households out of the 650 approached, agreed to participate), and 481 completed questionnaires were retained and used for subsequent data analysis.

\subsection{Questionnaire development}

The questionnaire comprised three main sections (Appendix A). The first section aimed to measure residents' place image by asking participants to indicate whether Kavala possessed certain attributes, using a Likert-type scale $(1=$ strongly disagree to $5=$ strongly agree). The attributes items were derived from past studies on residents' destination image (Henkel et al., 2006; Schroeder, 1996; Sterquist-Witter, 1985) as well as the broader literature of destination image (Baloglu \& McCleary 1999; Beerli \& Martin, 2004; Chen \& Tsai, 2007; Echtner \& Ritchie, 2003; Gallarza et al., 2002). Attention was also given to attributes used in place and city image literature (Carrillo, 2004; Hankinson, 2004; Merrilees et al. 2009; Santos, Martins \& Britoet, 2007). The selection of attributes was based on several general guidelines. First, given the variety of attributes available in the literature, attention was given to "universal attributes" (e.g., public services, safety), excluding attributes which may not be suitable to the context of Kavala or the residents' perspective (such as availability of golf facilities, value for money). Second, to reflect the multifunctional nature of the place to residents, emphasis was given to attributes reflecting residents' experience of the place as a place to live and work as well as a tourism and recreational setting. Particular attention was given to attributes common across destination image studies and city image literature (e.g., friendly residents, shopping) as well as attributes which have been overlooked by previous studies of residents' place image in tourism (e.g., job opportunities, community services). Third, emphasis was given to functional attributes, as these are more controllable and manageable by tourism development (Green, 1999).

The second section of the questionnaire captured residents' perception of the three 
domains of tourism impacts. Perceived economic impacts were measured by five items adopted from previous studies (Gursoy \& Rutherford, 2004; Lee, Li, \& Kim, 2007; McDowall \& Choi, 2010; Nunkoo \& Ramkissoon, 2010). Six measurement items were used to capture perceived socio-cultural impacts (Andriotis \& Vaughan, 2003; Dyer et al., 2007, Jurowski et al., 1997; Gursoy \& Rutherford, 2004; Terzidou et al., 2008). Perceived environmental impacts were evaluated using four items (based on Bestard \& Nadal, 2007; Byrd, Bosley \& Dronberger, 2009; Gursoy \& Rutherford, 2004; Gu \& Ryan, 2008). The use of measurement items from various sources helped to mitigate the issue of common method variance amongst perceived economic, socio-cultural and environmental impacts (Podsakoff et al., 2003). Following the non-forced approached, the measurement items of the perceived impacts were phrased in a neutral position (with a bipolar scale ranging from $1=$ strong negative to $5=$ strong positive, with 3 indicating no change) so that respondents had the freedom to indicate the extent to which they perceived those impacts as being positive or negative (Andereck et al., 2005; Ap \& Crompton, 1998; Deccio \& Baloglu, 2002; Jurowski et al., 1997).

In the third section, residents' support for tourism development was measured by three statements, with a Likert-type scale (1= strongly disagree to $5=$ strongly agree). The first statement captured residents' general support for further tourism development (Ko \& Stewart, 2002; McGehee \& Andereck, 2004). Since Kavala is in the initial stages of the destination life cycle (Butler, 1980), the second statement focused on residents' support for public funding of tourism development (Schroeder, 1996). Similarly, in this case further development is likely to involve an increase in the volume of tourists to the city (Butler, 1980; Nepal, 2008). Particularly, as Kavala's tourism industry and its current marketing and development plans are focused on the general mass tourism market (Kavala Municipality, 2013). Thus, the third item captured residents' support for increasing the number of tourists to the city (Andereck \& Vogt, 2000; Latkova \& Vogt, 2012; McGehee \& Andereck, 2004; Nepal, 2008).

The questionnaire was written in English and translated into Greek under the principles of blind translation-back-translation method (Brislin, 1976). To assure the reliability of the translated version, a professional translator and language editor took part in this process. To assess the face and content validity of the questionnaire six Greek tourism experts (tourism academics, hotel owners in Kavala and representatives of the Kavala Tourism Organization) and a sample of Kavala's residents $(n=10)$ were recruited to review the questionnaire (following Netemeyer, Bearden \& Sharma, 2003). Participants were asked to comment on the suitability and clarity of the items, as well as suggest any key items which might be missing. Several place image items (exotic, natural wonders, modern day design) were identified as less relevant to the context of Kavala and were removed from the initial list, resulting in 14 attributes. There was no change to the number of items measuring perceived impacts or support for development. Finally, a pilot test aiming to evaluate the clarity of the questionnaire was conducted with 65 residents of Kavala. The final version of the questionnaire was reached after minor amendments based on their comments (Appendix A). 


\subsection{Data analysis}

Following a preliminary data screening (missing values and normality) and review of the descriptive statistics, the analysis strategy consisted of three stages. First, the dimensionality of the key constructs in the model was evaluated. To identify the dimensions underpinning residents' place image, an Exploratory Factor Analysis (EFA) was used. The uni-dimensionality of the perceived impacts and the support for tourism development constructs was tested with a Confirmatory Factor Analysis (CFA). This aims to assure that each set of alternate indicators has only one underlining construct in common (Sethi \& King, 1994). Second, the measurement model was evaluated for its reliability and validity. Third, the structural relationships between residents' place image, perceived economic impacts, perceived socio-cultural impacts, perceived environmental impacts, and residents' support for tourism development were tested.

\section{Findings}

\subsection{Sample profile}

The participants of this study are a close representation of Kavala's population. As seen from Table 2, similar to the information from the recent census, there was an almost equal distribution between males and females in the sample. Residents aged over 65 years were the largest group in the sample, followed by the age group of 25-34. Most of the participants were long-term residents and indicated that they had been living in Kavala for over 20 years. In terms of income, about a third of the participants reported annual earnings between 10,000 and 19,999€ (1€=1.33US\$ as of 10 August 2013).

\section{[Table 2]}

\subsection{Missing data and normality}

The data were screened for suitability and applicability before performing the SEM. Several missing values were identified, but they were deemed as trivial and thus no corrective action was needed. Namely, the number of missing values per variable was below 5\% (Tabachnick \& Fidell, 2013) and the Little's MCAR test was not significant, indicating that the missing values occurred on a random basis (Meyers, Gamst, \& Guarino, 2006). The skewness and kurtosis values (Appendix B), indicated no major issues with regard to the normality distribution. Moreover, some departures from normality are expected in social science research and these are not considered problematic when the sample size is large (Hair et al., 2010).

\subsection{Descriptive statistics}


Participants generally displayed a favorable image of Kavala, with the overall mean score slightly over 3 (Appendix B). Particularly, participants appreciated Kavala's scenery, pleasant weather and sense of safety. In contrast, the availability of quality job opportunities, nightlife and entertainment, and the effectiveness of the local government were perceived in the least favorable manner. Participants were given the autonomy to rate the degree to which they evaluate tourism as having a positive or negative effect on the economic, socio-cultural, and environmental domains of community life. The economic impacts were generally rated as positive with an overall mean score above 3 . Specifically, participants perceived the impact on the city's revenues and the standard of living as the most favorable. Even so, tourism is perceived to have worsened the state of land/housing prices. The socio-cultural impacts were also rated favorably (all measurement items but one ranked over 3). Respondents particularly valued the opportunities to engage in cultural exchange, and the availability of cultural activities, but considered tourism to have a somewhat negative effect on crime rates. Finally, participants suggested tourism had degraded the environmental conditions of Kavala (all its items ranked under 3) and mainly the level of traffic congestion and crowding. Considering these, participants were generally supportive of further tourism development with an overall mean score of 3.92 .

\subsection{Constructs' dimensionality}

\subsubsection{Resident's place image}

EFA was performed using the principal component analysis method (promax rotation) to determine the dimensionality of residents' place image. The results revealed four distinct factors, explaining $60.07 \%$ of the total variance (Table 3). All items were loaded above 0.4 on one factor only, with no item cross-loading above 0.4 on multiple factors (Hair et al., 2010), and the Cronbach's alpha values of all four factors were above the suggested benchmark of 0.6 (Nunnally \& Bernstein, 1994). The factors were labeled based on the core items constituting them. The first factor, "community services", refers to the quality of job opportunities and the effectiveness of public services and local government. The second factor, "physical appearance", reflects the importance of the physical characteristics of the city, such as its scenery and architecture. The third factor, "social environment", focuses on residents' sense of safety and friendliness of community members. The fourth factor labeled "entertainment services" relates to the availability of leisure and recreation activities. The overall mean scores suggest residents particularly appreciate the city's physical appearance and social environment, whereas entertainment and community services were ranked lower. For the subsequent multivariate analysis, these four factors were converted into four composite variables (based on mean scores), to be used as indicators for the latent construct of "residents' place image". This approach is commonly applied to mitigate potential multicollinearity associated with the multiple dimensions and indicators of the latent construct and to lessen model complexity, which can undermine the model's goodness-of-fit and predictive validity (Bollen, 1989; Chen \& Phou, 2013; Hair et al., 2010). Specifically, the use of composite variables was preferred over the use of a higher-order construct for residents' 
place image (i.e., retaining the original 14 items) since a higher-order construct could increase the measurement error in the latent construct, due to the multiple errors associated with the various single items. This could consequently weaken the predictive validity and the goodness-of-fit of the structural model and complicate the interpretation of the model (Hair et al. 2010). However, the composite variables approach is not without its drawbacks. Mainly, representing a latent construct with composite variables may weaken its convergent validity (for example, the AVE value, see Hair et al., 2010; von der Heidt \& Scott, 2007), which was the case of residents' place image in this study (see further discussion in section 4.5).This drawback was considered acceptable for the purpose of the current study, which focuses on clarifying the structural relationships between residents' place image, perceived impacts and their support for tourism.

\section{[Table 3]}

\subsubsection{Perceived impacts and support}

The uni-dimensionality and construct validity of the three impact constructs and the residents' support construct were tested with CFA. Two items (crime, public services) of the perceived socio-cultural impacts displayed poor discriminant validity and thus were deleted from further analysis (Hair et al., 2010; Tabachnick \& Fidell, 2013). It seems that residents of Kavala do not directly associate tourism with an increase in crime levels. In fact, Kavala is considered among the safest urban environments in Greece (Hellenic Police, 2013). Additionally, residents may not recognize tourism as affecting local services, due to the fact that Kavala is still in an initial stage of tourism development.

\subsection{Measurement model}

Following the two step approach (Anderson \& Gerbing, 1988), before testing the hypotheses, a CFA of the measurement model (maximum likelihood estimation method) was conducted to establish the reliability and validity (convergent, discriminant) of the study's constructs. As shown in Table 4, the composite reliability estimates of all constructs exceeded the recommended threshold of 0.70 , indicating that the measures are reliable (Nunnally \& Bernstein, 1994). To assess convergent validity, standardized factor loadings and Average Variance Extracted (AVE) were used. From Table 4, all standardized factor loadings were above 0.5, and significant at $p<0.001$ (Tabachnick \& Fidell, 2013). The AVE reflects the amount of variance captured by the construct in relation to the amount of variance due to measurement error, and in this study all the AVE values were above 0.5 (Fornell \& Larcker, 1981; Hair et al., 2010), apart from the case of residents' place image (0.41). The lower AVE of residents' place image could be attributed to the use of composite variables to represent this construct (see Hair et al., 2010; von der Heidt \& Scott, 2007), and it was deemed tenable for several reasons. First, as discussed in section 4.4.1, while the use of composite variables may weaken the convergent validity, it contributes to retaining the predictive validity of a latent construct in relation to other constructs (Hair et al., 2010). The predictive validity of the 
residents' place image construct is particularly imperative to this study, which focuses on the structural relationships between residents' place image, perceived impacts, and support for tourism development. Second, beyond the AVE, the other convergent validity criteria of residents' place image were satisfactory, whereby the standardized factor loadings of all its measurement items were above 0.5 and significant at $\mathrm{p}<0.001$ (Hair at al., 2010; Steenkamp \& Van Trijp, 1991; Tabachnick \& Fidell, 2013), with construct reliability of 0.71 (Hair el al., 2010; Fornell \& Larcker, 1981). Third, in the EFA, the total variance explained for residents' place image was $60.07 \%$, which further indicates a satisfactory convergent validity (Hair et al., 2010). Discriminant validity was examined by comparing the AVE values with the squared correlations between paired constructs. All the AVE estimates were higher than the inter-construct squared correlations (Table 5), indicating that each construct is statistically different from the others (Fornell \& Larcker, 1981; Hair et al., 2010). Finally, the fit indices suggest that the measurement model is acceptable with $\chi_{(160)}^{2}=371.2(p<0.001), \mathrm{CMIN} / \mathrm{DF}=$ 2.32, $\mathrm{CFI}=0.96, \mathrm{GFI}=0.93, \mathrm{SRMR}=0.05$ and $\mathrm{RMSEA}=0.05$ (Blunch, 2008; Hair et al. 2010; Kline, 2010; Tabachnick \& Fidell, 2013).

[Table 4]

[Table 5]

\subsection{Structural model}

The hypothesized relationships among the study's constructs were tested in the structural model (maximum likelihood estimation method). The results indicate a good fit of the structural model with $\chi_{(163)}^{2}=497.84(p<0.001), \mathrm{CMIN} / \mathrm{DF}=3.05, \mathrm{CFI}=0.93$, GFI= 0.91, $\mathrm{SRMR}=0.07$ and $\mathrm{RMSEA}=0.06$. Thus, the hypothesized model was a good fit for the empirical data. As seen on Table 6, the seven hypothesized relationships (paths) constituting the structural model were significant in the expected direction. Hence, all of the proposed hypotheses were accepted, and their implication to tourism development theory and practice is discussed in the following section.

[Table 6]

\section{Conclusion}

This study explores residents' support for tourism development by drawing on the triple bottom line approach and adopting a non-forced approach for measuring residents' perceptions of the economic, socio-cultural and environmental impacts of tourism. Additionally, the role of residents' place image in shaping their perception of impacts and support for tourism development was investigated. As such, this study extends the SET framework to incorporating another determinant of residents' support, which has been largely overlooked thus far. The validity and reliability of the proposed model of the structural relationships between residents' place image, perceived impacts and residents' support for 
tourism development (Figure 1) was supported along with its inherent seven hypotheses. The findings offer several insights to scholars and practitioners that seek to understand and solicit residents' support for tourism development.

The current findings reinforce the proposition of SET and previous studies (e.g., Gursoy, et al., 2010; Jurowski et al., 1997), whereby residents are more likely to support tourism development if they expect its benefits to outweigh the potential negative impacts. Specifically, the findings have established positive significant relationships between all three domains of perceived impacts and residents' support. Hypothesis H1 was supported, suggesting that a more favorable perception of economic impacts leads to greater support for further development. This reflects the common view of tourism as a tool for economic development of local communities (Gursoy et al., 2002; Prayag et al., 2013). Similarly, it was found that the more positively residents perceive its socio-cultural impacts the more likely they are to support tourism development (H2). The confirmation of $\mathrm{H} 1$ and $\mathrm{H} 2$ is in line with Jurowski et al. (1997), who also relied on a non-forced approach in the measurement of tourism impacts. Hypothesis $\mathrm{H} 3$ was also supported, indicating that the more (less) positively residents judge the environmental impacts of tourism, they display greater (lesser) support for development. This is partially in line with Jurowski et al. (1997), who reveal a positive but insignificant effect of perceived environmental impacts on support. This difference can be attributed to the fact that Jurowski et al. (1997) used only one item to assess perceived environmental impacts, whereas the current study used a more comprehensive measurement (with four items). Furthermore, the context of the two studies differs in that Jurowski et al. (1997) explored nature based tourism in a rural area, while this study focused on mainstream general tourism in a developing urban destination. Issues of traffic, congestion, etc. are more salient to those living in an urban destination (Andereck et al., 2005), whereas niche tourism developments (as nature tourism) are generally perceived as having less evident environmental impacts (Dyer et al., 2007; Gursoy, et al., 2010). The confirmation of these hypotheses emphasizes the importance of adopting a non-forced approach for measuring tourism impacts. Unlike previous approaches (i.e., costs-benefits and domain related costsbenefits), which merely rely on what researchers consider to be positive or negative impacts, the non-forced approach captures residents' subjective evaluation of the diverse impacts of tourism. It could be said that the non-forced approach better resonates with the SET, which emphasizes the individual's own perception of the potential costs and benefits involved in the exchange process.

The findings also contribute toward a deeper understanding of the "exchange" process specified by the SET, by considering the distinct effect of each perceived impact domain (economic, socio-cultural and environmental) on residents' support. While supporting the general proposition of the SET, the findings further emphasize that the importance residents assign to the various tourism impacts in shaping their support contextually depends on a place's peculiarities such as economic conditions and stage of tourism development. As evident in relation to Kavala, perceived economic impacts have the strongest effect, followed by socio-cultural impacts, with environmental impacts having the weakest effect on residents' 
support. This is not entirely surprising, since the potential economic benefits are both easy to observe and are often the most valued by local authorities and residents (Gursoy et al., 2002; Prayag et al., 2013). Moreover, as this study was conducted during an economic recession in Greece, this may have accentuated the importance of economic and socio-cultural impacts over the environmental consideration (Nunkoo \& Ramkissoon, 2012; Vargas-Sánchez et al., 2009). The small and community-focused nature of Kavala as well as the collectivist culture of Greece (Hofstede Centre, 2013) may have also contributed to the importance of perceived socio-cultural impacts in securing residents' support. On the other hand, the weaker effect of the environmental impacts on residents' support can be attributed to the fact that Kavala is in its initial stage of tourism development. The environmental impacts of tourism may be more acute and apparent to residents in the longer term, as tourism to the destination develops further (Dyer et al., 2007). Additionally, Dyer et al.'s (2007) observation that there is commonly less awareness or ability to assess the environmental impacts of tourism might be particularly true in relation to newly developed destinations. Although most past studies based on the SET have considered residents' support as the result of a simple weighting of costs versus benefits, the current study suggests that residents engage in a more complex evaluation of the exchange they are about to enter. One which involves a simultaneous weighting of the various forms of impacts, as well as the particular context of the place they live in. This notion emphasizes the need to adopt the triple bottom line approach to tourism impacts to gain a holistic understanding of the underlining experiential and cognitive functions shaping residents' support.

This research advances the current tourism development literature by further extending the SET framework and examining residents' place image and the manner it shapes community reaction to tourism. While residents' place image has received limited attention thus far (Ramkissoon \& Nunkoo, 2011), it plays a key role in influencing community perception and support for tourism development. More specifically, the current findings support Schroeder's (1996) initial results, and indicate structural relationships between residents' place image and their support for development, revealing that a more positive place image is likely to enhance residents' support for tourism development (H7 supported). Similar to Ramkissoon and Nunkoo (2011), our findings suggest that residents' place image also has a positive effect on their perception of tourism impacts (H4, H5 and H6 supported). Moreover, this study further advances the understanding of these relationships, by verifying the effect of residents' place image on the various domains of perceived tourism impacts (economic, sociocultural, environmental), whereas Ramkissoon and Nunkoo (2011) have merely examined perceived impacts at a summative and generic level (as "overall tourism impacts"). Specifically, the current findings reveal that a more positive residents' place image leads to more favorable perceptions of the economic, socio-cultural as well as environmental impacts of tourism. These findings suggest that place image is the "lens" through which residents judge the impacts of tourism, whereas positive disposition toward the place leads to a more soft and favorable evaluation of tourism impacts (and greater support), and a less positive image leads to harsher judgment (and subsequently less support). However, it should be noted that the relative strength of the relationships between residents' place image and each of the 
perceived impacts may vary depending on the context. For example, in relation to Kavala, which is in the initial stage of the destination life cycle and the environmental impacts of tourism may be less evident (Butler, 1980; Dyer et al., 2007), place image exercises a weaker effect on the perceived environmental impact, in comparison to its effect on perceived economic and socio-cultural impacts.

The theoretical contribution of this study to tourism development research is two-fold. First, this study addresses methodological issues in the measurement of perceived tourism impacts. The findings demonstrate the validity of a model of residents' support, using the triple bottom line approach and a non-forced measurement. Three distinct domains of perceived impacts displaying good level of construct validity and reliability were identified here (i.e., economic, socio-cultural, and environmental). Similar to past studies (e.g., Yoon, Gursoy \& Chen, 2001), the perceived economic and socio-cultural impacts of tourism were generally seen as positive, and the perceived environmental impacts of tourism were negatively associated. Even so, the non-forced approach also provides a more nuanced understanding of residents' perception. For example, in the case of Kavala the findings indicate that residents perceive tourism to have a negative effect on the price of land/housing and the level of crime. It is suggested that to advance tourism development research further, scholars should go beyond what they believe to constitute a positive or negative impact on the host community and offer more freedom to the local residents when gauging their perceived impacts of tourism as benefiting or harming their own community.

Second, the findings stress the importance of exploring place image not only in relation to tourists, as commonly done in tourism literature, but also in the context of the host community. This study directly responds to Ramkissoon and Nunkoo's (2011) and Schroeder's (1996) call for a more rigorous and theoretically based investigation into the nature of residents' place image and its role in shaping their attitudes and behavior towards the tourism industry. To do that a more comprehensive model that explains the structural relationships between residents' place image, perceived tourism impacts and support has been developed and tested. Particularly, in contrast to previous studies (Ramkissoon \& Nunkoo, 2011; Schroeder, 1996), this model recognizes the various domains of tourism impacts and encapsulates both the direct and indirect effects of residents' place image on their support. The findings provide a more in-depth understanding of how residents evaluate the "exchange" (i.e., the various positive and negative impacts) involved in tourism development, how this evaluation is shaped by their perceived image of the place (cognitive input), and how the perceived "exchange" and image intertwine in shaping residents' subsequent support for tourism development (behavioral outputs).

In this context, the current investigation also provides a more comprehensive framework for measuring residents' place image in future studies, which reflects the multifunction nature of the place to local residents. Different from previous studies that have emphasized either the tourism related attributes or attributes related to the function of the place as a work and residential setting (e.g., Ramkissoon \& Nunkoo, 2011; Schroeder, 1996), 
the current framework covers both destination and community related attributes and is comprised of four dimensions. These include: 1) community services, 2) physical attributes, 3) social environment and, 4) entertainment activities. "Community services" reflects the very basic requirements residents have from the place they live in and is analogous to the "government services" dimension noted in place marketing and branding studies (Merrilees et al., 2009; Santos et al., 2007). The other three relate to the physical and social characteristics, which give a place its' unique image (Merrilees et al., 2009). Namely, each place has distinct physical attributes (Morgan, Pritchard \& Pride, 2004) such as its scenery and heritage in relation to Kavala. The social fabric of the place is reflected in the social environment dimension in which safety and locals' friendliness are key elements. Similarly, entertainment activities (shopping, dining, etc.) are some of the ways in which people socially bond with a place (Merrilees et al., 2009). These dimensions highlight that tourism development studies must consider not only the attributes important for tourists, but also the diverse attributes valued and cherished by the local residents in order to facilitate sustainable development.

\subsection{Managerial implications}

The current study offers important insights for the practice of tourism development, planning and policy. It is suggested that to positively influence residents' perception of tourism impacts and encourage support for further development, tourism development plans should aim to comply with, or better still, improve the residents' image of their place. This can be achieved by identifying and addressing the negative attributes of the place's image and leveraging the positive attributes. For example, in relation to Kavala, developers should employ tourism to improve the city's quality of community services and provision of entertainment opportunities. To maintain support in the long run, local authorities could also engage in continuous internal marketing to highlight the positive aspects of the city's image and the potential contribution of tourism development to that image.

Additionally, while developers predominantly emphasize the economic impacts of tourism (Hardy, Robert, Beeton \& Pearson, 2002), the triple bottom line approach adopted here highlights the importance of considering a wider spectrum of tourism impacts (i.e., economic, socio-cultural, and environmental). Moreover, developers should be cognizant that the emphasis local residents place on these impacts depends on various situational factors such as the destination's stage of development, the state of economy or cultural values. To gain residents' support, local authorities and developers need to balance local residents' priorities with commercial priorities prudently. For example, in the case of Kavala, current development plans should give emphasis to enhancing and communicating to residents the economic and socio-culture impacts of tourism to achieve greater support. Moreover, as the conditions of the destination may change over time, residents' perception of tourism impact and their effect on support for further development should be constantly monitored and managed.

Finally, the non-forced approach provides a more resident-based understanding of 
perceived impacts. With such knowledge local authorities can strategically devise educational programs to secure local residents' support and even involvement in development projects. These programs should communicate to residents the positive and negative impacts tourism may have on their community. Such programs may be particularly effective for newly developing destinations, as in the case of Kavala, where residents may be less aware of the various potential impacts (Dyer et al., 2007). For example, residents may not be aware of the multiplier effect and the ability of tourism to yield wider economic and regional development due to its strong relations with other sectors (Hardy et al., 2002). Similarly, residents may have limited knowledge of the potential (positive and negative) environmental implication of tourism development. Such lack of awareness may hinder the progression and success of development projects. Empowering residents via the provision of information on the potential implications of tourism could facilitate residents' support by improving their trust in local authorities and leading to more effective and sustainable development plans (Nunkoo \& Ramkissoon, 2012).

\subsection{Limitations and future research}

This study has several limitations which provide opportunities for further research. First, the proposed model was tested only in relation to one recently developed destination and thus, the generalizability of the findings may be limited. Further validation of the model in other regions is required since tourist destinations vary in relation to their image characteristics, the extent of tourism development and its impacts. Second, this study was conducted during a particular point in time and circumstances (economic downturn). Residents' place image and their perceptions of tourism impacts are dynamic, and may change over different stages of the destination's lifecycle, and as circumstances transform. Further research could explore the model proposed here over time and thus provide a much-needed longitudinal approach to tourism development studies.

Third, the proposed model has primarily focused on residents' place image as the antecedent of the perceived tourism impacts and their support for tourism development. Future research may consider additional antecedents, such as residents' personal economic gain and direct/indirect involvement with tourism (e.g., Gursoy et al., 2010), which might further explain residents' support for tourism. Particularly, given the differing nature of place image and place attachment, a future study could explore the role of both of these constructs in shaping residents' reaction to tourism development. Fourth, while the measurement of residents' place image in this study shows promising validity and reliability, the use of composite variables to represent this construct may have weakened its convergent validity. A possible avenue to treat this issue in future research could be treating the multiple dimensions of residents' place image as multiple, distinctive, latent constructs in the structural model. This approach will also enable examining the distinctive effect of each dimension of place image on perceived impacts and support. Finally, this study has primarily focused on the functional attributes of place image. To further enhance the conceptualization and measurement of residents' place image future studies may consider including psychological 
Please reference as: Stylidis, D., Biran, A., Sit, J., \& Szivas, E. M. (2014). Residents' support for tourism development: The role of residents' place image and perceived tourism impacts. Tourism Management, 45(0), 260-274. doi: http://dx.doi.org/10.1016/j.tourman.2014.05.006

attributes (e.g., fame/reputation, atmosphere, see Echtner \& Ritchie, 2003) or affective attributes (e.g., relaxing, exciting, pleasant, see Lin, Morais, Kerstetter, \& Hou, 2007).

\section{References}

Akis, S., Peristianis, N., \& Warner, J. (1996). Residents' attitudes to tourism development: The case of Cyprus. Tourism Management, 17(7), 481-494.

Andereck, K.L., \& Vogt, C.A. (2000). The Relationship between Residents’ Attitudes toward Tourism and Tourism Development Options. Journal of Travel Research, 39(1), 27-36.

Andereck, K.L., Valentine, K.M., Knopf, R.C., \& Vogt, C.A. (2005). Residents' perceptions of community tourism impacts. Annals of Tourism Research, 32(4), 1056-1076.

Anderson, J.C., \& Gerbing, D.W. (1988). Structural equation modeling in practice: A review and recommended two-step approach. Psychological Bulletin, 103(3), 411-423.

Andersson, T.D., \& Lundberg, E. (2013). Commensurability and sustainability: Triple impact assessments of a tourism event. Tourism Management, 37(1), 99-109.

Andriotis, K. (2005). Community groups' perceptions of and preferences for tourism development: Evidence from Crete. Journal of Hospitality and Tourism Research, 29(1), 67-90.

Andriotis, K., \& Vaughan, R.D. (2003). Urban residents' attitudes toward tourism development: The case of Crete. Journal of Travel Research, 42(2), 172-185.

Ap, J. (1992). Residents' perceptions on Tourism Impacts. Annals of Tourism Research, 19(4), 665-690.

Ap, J., \& Crompton, J. (1998). Developing and testing a tourism impact scale. Journal of Travel Research, 37(2), 120-130.

Ashworth, G.J., \& Voogd, H. (1990). Selling the city. London: Belhaven Press.

Baloglu, S., \& McCleary, K.W. (1999). U.S. international pleasure traveller's images of four Mediterranean destinations: A comparison of visitors and non-visitors. Journal of Travel Research, 38(2), 144-152.

Bandyopadyay, R., \& Morrais, D. (2005). Representative dissonance: India's self and Western image. Annals of Tourism Research, 32(4), 1006-1021.

Beerli, A., \& Martin, J. (2004). Tourists' characteristics and the perceived image of tourist destinations: a quantitative analysis-a case study of Lanzarote, Spain. Tourism Management, 25(5), 623-636.

Bestard, A.B., \& Nadal, J.R. (2007). Modelling environmental attitudes toward tourism. Tourism Management, 28(3), 688-695.

Bigné, E., Sánchez, I., \& Sanz, S. (2005). Relationships among residents' image, evaluation of the stay and post-purchase behavior. Journal of Vacation Marketing, 11(4), 291-302.

Blunch, N.J. (2008). Introduction to structural equation modeling using SPSS and AMOS. London: Sage.

Bollen, K.A. (1989). Structural equations with latent variables. New York: Wiley.

Bolton, R. (1992). Place prosperity vs. people prosperity revisited: An old issue with a new angle. Urban Studies, 29(2), 185-203.

Bowlby, J. (1969). Attachment and loss: Vol 1. Attachment. New York: Basic Books. 
Please reference as: Stylidis, D., Biran, A., Sit, J., \& Szivas, E. M. (2014). Residents' support for tourism development: The role of residents' place image and perceived tourism impacts. Tourism Management, 45(0), 260-274. doi: http://dx.doi.org/10.1016/j.tourman.2014.05.006

Bowlby, J. (1979). The making and breaking of affectional bonds. London: Tavistock.

Bramwell, B., \& Rawding, L. (1996). Tourism marketing images of industrial cities. Annals of Tourism Research, 23(1), 201-221.

Brislin, R.W. (1976). Back-translation for cross-cultural research. Journal of Cross-Cultural Psychology, 1(3), 185-216.

Butler, R.W. (1980). The concept of a tourist area cycle of evolution: Implications for management of resources. Canadian Geographer, 24(1), 5-12.

Byrd, E.T., Bosley, H.E., \& Dronberger, M.G. (2009). Comparisons of stakeholder perceptions of tourism impacts in rural eastern North Carolina. Tourism Management, 30(5), 693703.

Carrillo F. (2004). Capital cities: a taxonomy of capital accounts for knowledge cities. Journal of Knowledge Management, 8(5), 28-46.

Chen, C., \& Phou, S. (2013). A closer look at destination: Image, personality, relationship and Loyalty. Tourism Management, 36(1), 269-278.

Chen, C., \& Tsai, D., (2007). How destination image and evaluative factors affect behavioral intentions? Tourism Management, 28(4), 1115-1122.

Chionis, K. (2005). The history of Kavala. Kavala: Municipal Museum.

Choi, H.C., \& Murray, I. (2010). Resident attitudes toward sustainable community tourism. Journal of Sustainable Tourism, 18(4), 575-594.

Crompton, J.L. (1979). An assessment of the image of Mexico as a vacation destination and the influence of geographical location upon the image. Journal of Travel Research, 18(4), 18-23.

Cui, X., \& Ryan, C. (2011). Perceptions of place, modernity and the impacts of tourismDifferences among rural and urban residents of Ankang, China: A likelihood ratio analysis. Tourism Management, 32(3), 604-615.

Czaja, R., \& Blair, J. (2005). Designing surveys: A guide to decisions and procedures $2^{\text {nd }}$ $E d$.). London: Pine Forge Press.

Deccio, C., \& Baloglu, S. (2002). Non-host community resident reactions to the 2001 Winter Olympics: The spillover impacts. Journal of Travel Research, 41(1), 46-56.

Devine-Wright, P., \& Howes, Y. (2010). Disruption to place attachment and the protection of restorative environments: A wind energy case study. Journal of Environmental Psychology, 30(3), 271-280.

Dredge, D. (2010). Place change and tourism development conflict: Evaluating public interest. Tourism Management, 31(1), 104-112.

Dyer, P., Gursoy, D., Sharma, B., \& Carter, J. (2007). Structural modelling of resident perceptions of tourism and associated development on the Sunshine Coast, Australia. Tourism Management, 28(2), 409-422.

Echtner, C.M., \& Ritchie, J.R.B. (2003). The meaning and measurement of destination image. Journal of Tourism Studies, 14(1), 37-48.

Elliot, S., Papadopoulos, N., \& Kim, S.S. (2011). An integrative model of place image: Exploring relationships between destination, product, and country image. Journal of Travel Research, 50(5), 520-534. 
Please reference as: Stylidis, D., Biran, A., Sit, J., \& Szivas, E. M. (2014). Residents' support for tourism development: The role of residents' place image and perceived tourism impacts. Tourism Management, 45(0), 260-274. doi: http://dx.doi.org/10.1016/j.tourman.2014.05.006

Fishbein, M., \& Ajzen, I. (1975). Belief, attitude, intention, and behavior. Reading, MA: Addison-Wesley.

Fornell, C., \& Larcker, D.F. (1981). Evaluating structural equation models with unobservable variables and measurement error. Journal of Marketing Research, 18(1), 39-50.

Gallarza, M.G., Saura, L.G., \& García, H.C. (2002). Destination image: towards a conceptual framework. Annals of Tourism Research, 29(1), 56-78.

Govers, R., Go, F.M., \& Kumar, K. (2007). Promoting tourism destination image. Journal of Travel Research, 46(1), 15-23.

Graziano, A.M., \& Raulin, M.L. (2004). Research methods: A process of inquiry (5th ed.). New York: Pearson Education Group.

Green, R. (1999). Meaning and form in community perception of town character. Journal of Environmental Psychology, 19(1), 311-329.

Green, R. (2005). Community perceptions of environmental and social change and tourism development on the island of Koh Samui, Thailand. Journal of Environmental Psychology, 25(1), 37-56.

Gu, H., \& Ryan, C. (2008). Place attachment, identity and community impacts of tourismThe case of a Beijing hutong. Tourism Management, 29(4), 637-647.

Gursoy, D., Jurowski, C., \& Uysal, M. (2002). Resident attitudes: A structural modeling approach. Annals of Tourism Research, 29(1), 79-105.

Gursoy, D., \& Rutherford, D.G. (2004). Host attitudes toward tourism: An improved structural model. Annals of Tourism Research, 31(3), 495-516.

Gursoy, D., Chi, C.G., \& Dyer, P. (2010). Locals' attitudes toward mass and alternative tourism: The case of Sunshine Coast, Australia. Journal of Travel Research, 49(3), 381-394.

Hair, J.F., Black, W.C., Babin, B.J., \& Anderson, R.E. (2010). Multivariate data analysis $\left(7^{\text {th }}\right.$ Ed.). New Jersey: Pearson Education.

Hankinson, G. (2004). The brand images of tourism destinations: a study of the saliency of organic images. Journal of Product Branding Management, 13(1), 6-14.

Hardy, A., Robert, J.S., Beeton, S., \& Pearson, L. (2002). Sustainable tourism: An overview of the concept and its position in relation to Conceptualizations of tourism. Journal of Sustainable Tourism, 10(6), 475-496.

Harrill, R. (2004). Residents' attitudes toward tourism development: A literature review with implications for tourism planning. Journal of Planning Literature, 18(3), 251-266.

Hellenic Statistical Authority (2012). Statistical data base. From: $<$ http://www.statistics.gr/portal/page/portal/ESYE/PAGE-database> Retrieved 11.09 .13

Hellenic Statistical Authority (2013). Population Census 2011. From: $<$ http://www.statistics.gr/portal/page/portal/ESYE/PAGE-census2011> Retrieved 11.09.13.

Hellenic Police (2013). Crime statistics for 2008-2013. From: $<$ http://www.astynomia.gr/index.php?option=ozo_content\&lang='..'\&perform=view\&i

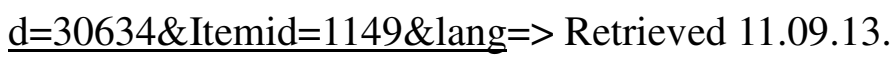


Please reference as: Stylidis, D., Biran, A., Sit, J., \& Szivas, E. M. (2014). Residents' support for tourism development: The role of residents' place image and perceived tourism impacts. Tourism Management, 45(0), 260-274. doi: http://dx.doi.org/10.1016/j.tourman.2014.05.006

Henkel, R., Henkel, P., Agrusa, W., Agrusa, J., \& Tanner, J. (2006). Thailand as a tourist destination: Perceptions of international visitors and Thai residents. Asia Pacific Journal of Tourism Research, 11(3), 269-287.

Hernández, B., Hidalgo, C.M., Salazar-Laplacea, M., \& Hess, S (2007). Place attachment and place identity in natives and non-natives. Journal of Environmental Psychology 27(4), 310-319.

Hidalgo, M. C. \& Hernández, B. (2001). Place attachment: Conceptual and empirical questions. Journal of Environmental Psychology, 21(3), 273-281.

Hofstede Centre (2013). What about Greece? From: <http://geert-hofstede.com/greece.html > Retrieved 11.09.13

Hsu, C.H.C., Wolfe, K., \& Kang, S.K. (2004). Image assessment for a destination with limited comparative advantages. Tourism Management, 25(1), 121-126.

Iroegbu, H., \& Chen, J.S. (2001). Urban residents' reaction toward tourism development: Do subgroups exist? Tourism Analysis, 6(2), 155-161.

Jurowski, C., \& Gursoy, D. (2004). Distance effects on residents' attitudes toward tourism. Annals of Tourism Research, 31(2), 296-312.

Jurowski, C., Uysal, M., \& Williams, D.R. (1997). A theoretical analysis of host community resident reactions to tourism. Journal of Travel Research, 36(2), 3-11.

Jutla, R.S. (2000). Visual image of the city: tourists' versus residents' perception of Simla, a hill station in northern India. Tourism Geographies, 2(4), 404-420

Kavala Municipality (2013). Kavala Municipality Website. From: $<$ http://www.kavala.gov.gr/web/guest/cityofkavala> Retrieved 23.09.13.

Kearsley, G.W. (1990). Tourism development and users' perceptions of wilderness in Southern New Zealand. Australian Geographer, 21(2), 127-140.

Kline, R.B. (2010). Principles and practice of structural equation modeling ( $3^{\text {rd }}$ Ed.). London: Guildford Press.

Ko, D.W., \& Stewart, W.P. (2002). A structural equation model of residents' attitudes for tourism development. Tourism Management, 23(5), 521-530.

Kotler, P, Haider, D., \& Rein, I. (1993). Marketing places. New York: The Free Press.

Latkova, P., \& Vogt, C.A. (2012). Residents' attitudes toward existing and future tourism development in rural communities. Journal of Travel Research, 51(1), 50-67.

Lee, T.J., Li, J., \& Kim, H.K. (2007). Community residents' perceptions and attitudes towards heritage tourism in a historic city. Tourism and Hospitality Planning and Development, 4(2), 91-109.

Lee, T.H. (2013). Influence analysis of community resident support for sustainable tourism development. Tourism Management, 34, 37-46.

Leisen, B. (2001). Image segmentation: The case of a tourism destination. Journal of Services Marketing, 15(1), 49-66.

Lewicka, M. (2011). Place attachment: How far have we come in the last 40 years? Journal of Environmental Psychology, 31(3), 207-230.

Lin, C.H., Morais, D.B., Kerstetter, D.L., \& Hou, J.S. (2007). Examining the role of cognitive and affective image in predicting choice across natural, developed, and theme-tark destinations. Journal of Travel Research, 46(2), 183-194. 
Please reference as: Stylidis, D., Biran, A., Sit, J., \& Szivas, E. M. (2014). Residents' support for tourism development: The role of residents' place image and perceived tourism impacts. Tourism Management, 45(0), 260-274. doi: http://dx.doi.org/10.1016/j.tourman.2014.05.006

Lynch, K. (1960). The image of the city. Cambridge: MIT Press.

McDowall, S., \& Choi, Y. (2010). A comparative analysis of Thailand residents' perception of tourism's impacts. Journal of Quality Assurance in Hospitality and Tourism, 11(1), 3655.

McGehee, N.G., \& Andereck, K.L. (2004). Factors predicting rural residents's support of tourism. Journal of Travel Research, 43(2), 131-140.

Merrilees, B., Miller, D., \& Herington, C. (2009). Antecedents of residents' city brand attitudes. Journal of Business Research, 62(3), 62-367.

Meyers, L., Gamst, G., \& Guarino, A. (2006). Applied multivariate research: Design and interpretation. London: Sage.

Morgan, N., Pritchard, A., \& Pride, R. (2004). Destination branding: creating the unique destination proposition ( $2^{\text {nd }} E d$.). Oxford: Butterworth-Heinemann.

Nepal, S.K. (2008). Residents' attitudes to tourism in Central British Columbia, Canada. Tourism Geographies, 10(1), 42-65.

Netemeyer, R.G., Bearden, W.O., \& Sharma, S. (2003). Scaling procedures: Issues and applications. Thousand Oaks, CA: Sage.

Nunkoo, R., \& Gursoy, D. (2012). Residents' support for tourism: An identity perspective. Annals of Tourism Research, 39(1), 243-268.

Nunkoo, R., \& Ramkissoon, H. (2010). Modeling community support for a proposed integrated resort project. Journal of Sustainable Tourism, 18(2), 257-277.

Nunkoo, R., \& Ramkissoon, H. (2011). Developing a community support model for tourism. Annals of Tourism Research, 38(3), 964-988.

Nunkoo, R., \& Ramkissoon, H. (2012). Power, trust, social exchange and community support. Annals of Tourism Research, 39(2), 997-1023.

Nunnally, J. C., \& Bernstein, I. (1994). Psychometric theory. New York: McGraw-Hill.

Podsakoff, P.M., MacKenzie, S.M., Lee, J., \& Podsakoff, N.P. (2003). Common method variance in behavioral research: a critical review of the literature and recommended remedies. Journal of Applied Psychology, 88(5), 879-903.

Prayag, G., Hosany, S., Nunkoo, R., \& Alders, T. (2013). London residents' support for the 2012 Olympic Games: The mediating effect of overall attitude. Tourism Management, $36,629-640$.

Ramkissoon, H., \& Nunkoo, R. (2011). City image and perceived tourism impact: Evidence from Port Louis, Mauritius. International Journal of Hospitality and Tourism Administration, 12(2), 123-143.

Raymond, C.M., Brown, G., \& Weber, D. (2010). The measurement of place attachment: Personal, community, and environmental connections. Journal of Environmental Psychology, 30(4), 422- 434.

Reiser, D., \& Crispin, S. (2009). Local Perception of the reimagining process. Journal of Place Management and Development, 2(2), 109-124.

Ryan, C. \& Cave, J. (2005). Structuring destination image: A qualitative approach. Journal of Travel Research, 44, 143-150

Santos, L., Martins, I., \& Brito, P. (2007). Measuring subjective quality of life: a survey to Porto's residents. Applied Research in Quality of Life, 2(1), 51-64. 
Please reference as: Stylidis, D., Biran, A., Sit, J., \& Szivas, E. M. (2014). Residents' support for tourism development: The role of residents' place image and perceived tourism impacts. Tourism Management, 45(0), 260-274. doi: http://dx.doi.org/10.1016/j.tourman.2014.05.006

Schroeder, T. (1996). The relationship of residents' image of their state as a tourist destination and their support for tourism. Journal of Travel Research, 34(4), 71-73.

Selvanathan, A., Selvanathan, S., Keller, G., Warrack, B., \& Bartel, H. (1994). Australian Business statistics. Melbourne: Nelson ITP.

Sethi, V., \& King, W. R. (1994). Development of measures to assess the extent to which an information technology application provides competitive advantage. Management Science, 40(12), 1601-1626.

Steenkamp, J.E.M., \& van Trijp, C.M. (1991). The Use of LISREL in Validating Marketing Constructs. International Journal of Research in Marketing, 8(4), 283-299.

Sternquist-Witter, B.S. (1985). Attitudes about a resort area: a comparison of tourists and local retailers. Journal of Travel Research, 24(1), 14-19.

Tabachnick, B.G., \& Fidell, L.S. (2013). Using Multivariate Statistics (6 ${ }^{\text {th }}$ ed.). New York: Pearson

Tasci A.D.A., \& Gartner, W.C. (2007). Destination image and its functional relationships. Journal of Travel Research, 45(4), 413-425.

Terzidou, M., Stylidis, D., \& Szivas, E. (2008). Residents' perceptions of religious tourism and its socio-economic impacts on the island of Tinos. Tourism and Hospitality Planning and Development, 5(2), 113-129.

Teye, V., Sönmez, S. F., \& Sirakaya, E. (2002). Residents' attitudes toward tourism development. Annals of Tourism Research, 29(3), 668-688.

Upchurch, R. S., \& Teivane, U. (2000). Resident perception of tourism development in Riga, Latvia. Tourism Management, 21(5), 499-507.

Vargas-Sánchez, A., Plaza-Mejia, M.A., \& Porras-Bueno, N. (2009). Understanding residents' attitudes toward the development of industrial tourism in a former mining community. Journal of Travel Research, 47(3), 373-387.

von der Heidt, T. \& Scott, D.R. (2007). Partial aggregation for complex structural equation modelling (SEM) and small sample sizes: An illustration using a multi-stakeholder model of cooperative interorganisational relationships (IORs) in product innovation. Paper presented at 21st Australian and New Zealand Academy of Managers Conference, Sydney, Australia. From: http://epubs.scu.edu.au/comm_pubs/25/ Retrieved 30.3.14.

Waters, E., Merrick, S., Treboux, D., Crowell, J., \& Albersheim, L. (2000). Attachment security in infancy and early adulthood: A twenty-year longitudinal study. Child Development, 7(3), 684-689.

Yoon, Y., Gursoy, D., \& Chen, J.S. (2001). Validating a tourism development theory with structural equation modeling. Tourism Management, 22(4), 363-372. 
Please reference as: Stylidis, D., Biran, A., Sit, J., \& Szivas, E. M. (2014). Residents' support for tourism development: The role of residents' place image and perceived tourism impacts. Tourism Management, 45(0), 260-274. doi: http://dx.doi.org/10.1016/j.tourman.2014.05.006 
Please reference as: Stylidis, D., Biran, A., Sit, J., \& Szivas, E. M. (2014). Residents' support for tourism development: The role of residents' place image and perceived tourism impacts. Tourism Management, 45(0), 260-274. doi: http://dx.doi.org/10.1016/j.tourman.2014.05.006

Table 2. Sample profile

\begin{tabular}{|c|c|c|c|c|}
\hline \multirow{2}{*}{$\frac{\text { Demographic }}{\text { Gender }}$} & \multicolumn{2}{|c|}{ Sample $(n=481)$} & \multicolumn{2}{|c|}{ Kavala Census $2011^{a}$} \\
\hline & Male & $47 \%$ & Male & $48 \%$ \\
\hline & Female & $53 \%$ & Female & $52 \%$ \\
\hline \multirow[t]{6}{*}{ Age group } & $18-24$ & $12.1 \%$ & $15-24$ & $16.9 \%$ \\
\hline & $25-34$ & $18.5 \%$ & $25-34$ & $17.8 \%$ \\
\hline & $35-44$ & $17.9 \%$ & $35-44$ & $17.3 \%$ \\
\hline & $45-54$ & $16.4 \%$ & $45-54$ & $15.7 \%$ \\
\hline & $55-64$ & $13.4 \%$ & $55-64$ & $12.9 \%$ \\
\hline & 65 and above & $21.4 \%$ & 65 and above & $20.0 \%$ \\
\hline \multirow{3}{*}{$\begin{array}{l}\text { Length of } \\
\text { residency (years) }\end{array}$} & $1-9$ & $15 \%$ & \multirow{3}{*}{\multicolumn{2}{|c|}{$\mathrm{NA}^{\mathrm{b}}$}} \\
\hline & $10-19$ & $17 \%$ & & \\
\hline & 20 and more & $68 \%$ & & \\
\hline \multirow{5}{*}{$\begin{array}{l}\text { Annual income } \\
(€)\end{array}$} & Less than 9,999 & $18 \%$ & \multirow{5}{*}{\multicolumn{2}{|c|}{$\begin{array}{l}\text { Average annual income } 10,200- \\
\qquad 12,650 €^{\mathrm{c}, \mathrm{d}}\end{array}$}} \\
\hline & $10,000-19,999$ & $35.4 \%$ & & \\
\hline & $20,000-29,999$ & $23.4 \%$ & & \\
\hline & $30,000-39,999$ & $12.6 \%$ & & \\
\hline & 40,000 and more & $10.6 \%$ & & \\
\hline
\end{tabular}

a Source: Hellenic Statistical Authority (2013). $b$ Information of length of residency is not available in the 2011 census. $c$ Only the average annual income figure is provided in the 2011 census. $d 1 €=1.33$ US\$ (as of 10 August 2013) 
Table 3. Exploratory factor analysis of residents' place image

\begin{tabular}{|c|c|c|c|c|c|}
\hline Factors/ Items & $\begin{array}{l}\text { Factor } \\
\text { loading }\end{array}$ & Eigenvalue & $\begin{array}{c}\% \text { of } \\
\text { variance } \\
\text { explaine }\end{array}$ & $\begin{array}{c}\text { Cronbach's } \\
\text { alpha }\end{array}$ & $\begin{array}{l}\text { Overall } \\
\text { Mean }\end{array}$ \\
\hline F1 Community services & & 4.34 & 31.00 & 0.73 & 2.69 \\
\hline Good job opportunities & 0.77 & & & & \\
\hline Effective public services & 0.73 & & & & \\
\hline Effective local government & 0.68 & & & & \\
\hline $\begin{array}{l}\text { Good public transportation } \\
\text { system }\end{array}$ & 0.64 & & & & \\
\hline F2 Physical appearance & & 1.77 & 12.63 & 0.74 & 3.84 \\
\hline Attractive scenery & 0.80 & & & & \\
\hline Pleasant weather & 0.75 & & & & \\
\hline Interesting historic sites & 0.72 & & & & \\
\hline Nice architecture & 0.67 & & & & \\
\hline F3 Social environment & & 1.23 & 8.77 & 0.68 & 3.46 \\
\hline Safe place to live & 0.85 & & & & \\
\hline Friendly locals & 0.69 & & & & \\
\hline Clean & 0.67 & & & & \\
\hline F4 Entertainment services & & 1.07 & 7.66 & 0.67 & 2.96 \\
\hline Good restaurants & 0.82 & & & & \\
\hline Good nightlife/ entertainment & 0.74 & & & & \\
\hline Good place for shopping & 0.62 & & & & \\
\hline
\end{tabular}

Total variance explained: $60.07 \%$. 
Table 4. The measurement model

\begin{tabular}{|c|c|c|c|c|}
\hline Constructs/ indicators & $\begin{array}{c}\text { Item } \\
\text { loadings }\end{array}$ & t-value & $\begin{array}{l}\text { Construct } \\
\text { reliability }\end{array}$ & AVE \\
\hline Residents'Place Image & & & 0.73 & 0.41 \\
\hline Community Services & 0.71 & $15.38^{*}$ & & \\
\hline Social environment & 0.63 & $13.52^{*}$ & & \\
\hline Entertainment & 0.62 & $13.24 *$ & & \\
\hline Physical Appearance & 0.55 & $11.55^{*}$ & & \\
\hline Economic Impacts & & & 0.87 & 0.57 \\
\hline Standard of living & 0.81 & $20.82^{*}$ & & \\
\hline Number of jobs & 0.79 & $19.90^{*}$ & & \\
\hline Infrastructure & 0.79 & $20.19^{*}$ & & \\
\hline Revenue in the economy & 0.77 & $19.42 *$ & & \\
\hline Price of land/housing & 0.55 & $12.59^{*}$ & & \\
\hline Socio-cultural Impacts & & & 0.81 & 0.52 \\
\hline Availability of recreational facilities & 0.79 & $19.57 *$ & & \\
\hline Cultural activities/ entertainment & 0.74 & $17.74 *$ & & \\
\hline $\begin{array}{l}\text { Opportunity to meet people from } \\
\text { other cultures }\end{array}$ & 0.72 & $17.29 *$ & & \\
\hline Community spirit & 0.59 & $13.16^{*}$ & & \\
\hline Environmental Impacts & & & 0.85 & 0.59 \\
\hline Crowding & 0.93 & $25.18^{*}$ & & \\
\hline Traffic congestions & 0.80 & $20.49^{*}$ & & \\
\hline Noise levels & 0.72 & $17.46^{*}$ & & \\
\hline Environmental pollution & 0.56 & $12.81^{*}$ & & \\
\hline Support for tourism development & & & 0.92 & 0.81 \\
\hline Public finance for tourism promotion & 0.91 & $25.58^{*}$ & & \\
\hline Further tourism development & 0.90 & $25.44^{*}$ & & \\
\hline Increase in the number of tourists & 0.88 & $24.20^{*}$ & & \\
\hline
\end{tabular}

$* p<0.001$ 
Please reference as: Stylidis, D., Biran, A., Sit, J., \& Szivas, E. M. (2014). Residents' support for tourism development: The role of residents' place image and perceived tourism impacts. Tourism Management, 45(0), 260-274. doi: http://dx.doi.org/10.1016/j.tourman.2014.05.006

Table 5. Correlation matrix

\begin{tabular}{lccccc}
\hline Constructs & $\begin{array}{c}\text { Residents' } \\
\text { Place Image }\end{array}$ & $\begin{array}{c}\text { Perceived } \\
\text { Economic } \\
\text { impacts }\end{array}$ & $\begin{array}{c}\text { Perceived } \\
\text { Socio-cultural } \\
\text { impacts }\end{array}$ & $\begin{array}{c}\text { Perceived } \\
\text { Environmental } \\
\text { impacts }\end{array}$ & $\begin{array}{c}\text { Support for } \\
\text { tourism }\end{array}$ \\
\hline $\begin{array}{l}\text { Residents' Place } \\
\text { Image }\end{array}$ & $\mathbf{0 . 4 1}^{\mathrm{a}}$ & & & & \\
$\begin{array}{l}\text { Perceived Economic } \\
\text { impacts }\end{array}$ & $0.22^{\mathrm{b}}$ & $\mathbf{0 . 5 7}$ & & & \\
$\begin{array}{l}\text { Perceived Socio- } \\
\text { cultural impacts }\end{array}$ & 0.24 & 0.50 & $\mathbf{0 . 5 2}$ & $\mathbf{0 . 5 9}$ & . \\
$\begin{array}{l}\text { Perceived } \\
\text { Environmental }\end{array}$ & 0.04 & 0.01 & 0.02 & & $\mathbf{0 . 8 1}$ \\
$\begin{array}{l}\text { impacts } \\
\text { Support for tourism }\end{array}$ & 0.40 & 0.44 & 0.44 & 0.07 & \\
\hline
\end{tabular}

a Average variance extracted. $b$ Inter-construct squared correlations. 


\section{Table 6. Estimated standardized coefficients}

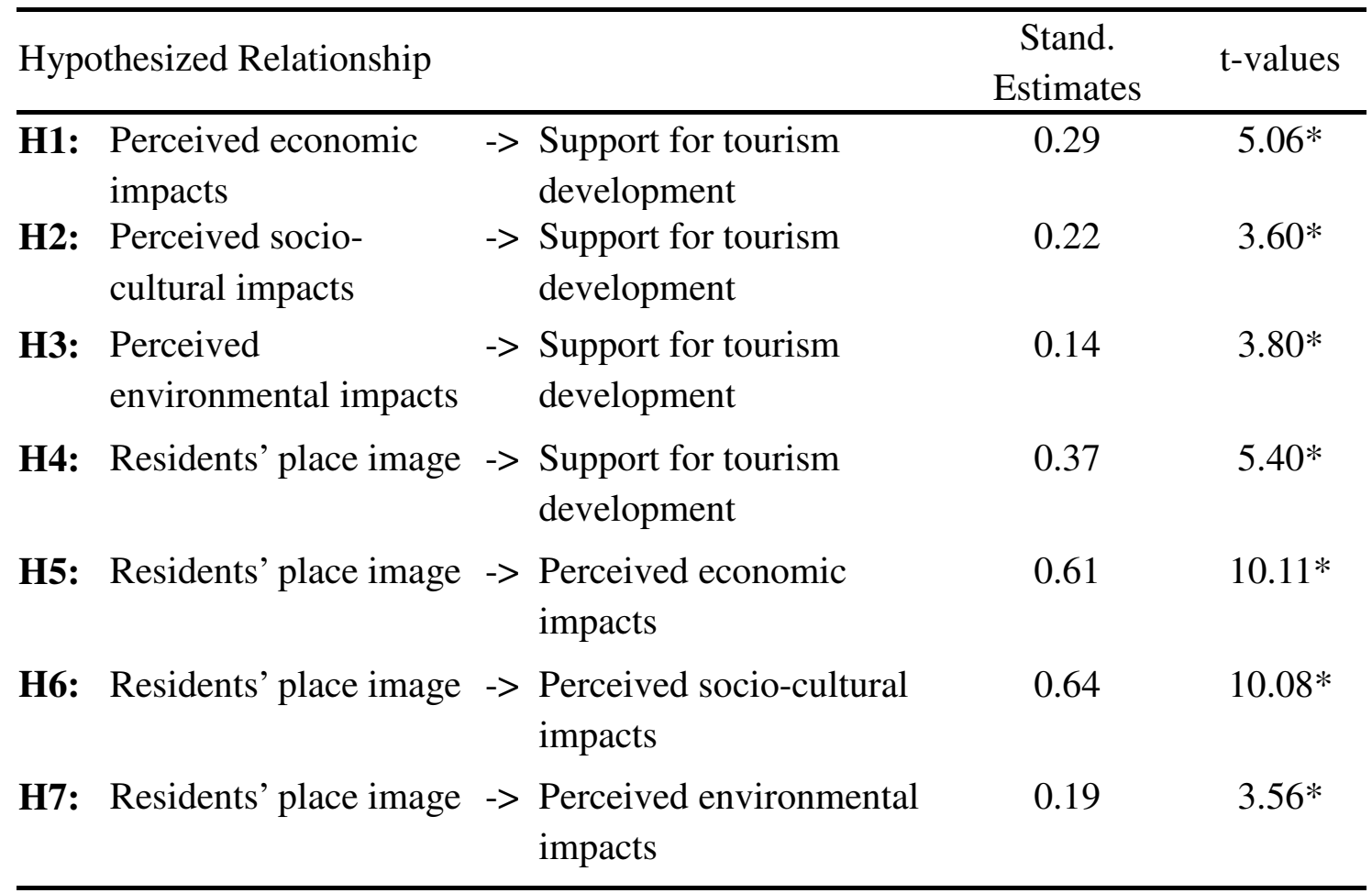

$* p<0.001$ 
Please reference as: Stylidis, D., Biran, A., Sit, J., \& Szivas, E. M. (2014). Residents' support for tourism development: The role of residents' place image and perceived tourism impacts. Tourism Management, 45(0), 260-274. doi: http://dx.doi.org/10.1016/j.tourman.2014.05.006

Figure 1. The proposed theoretical model

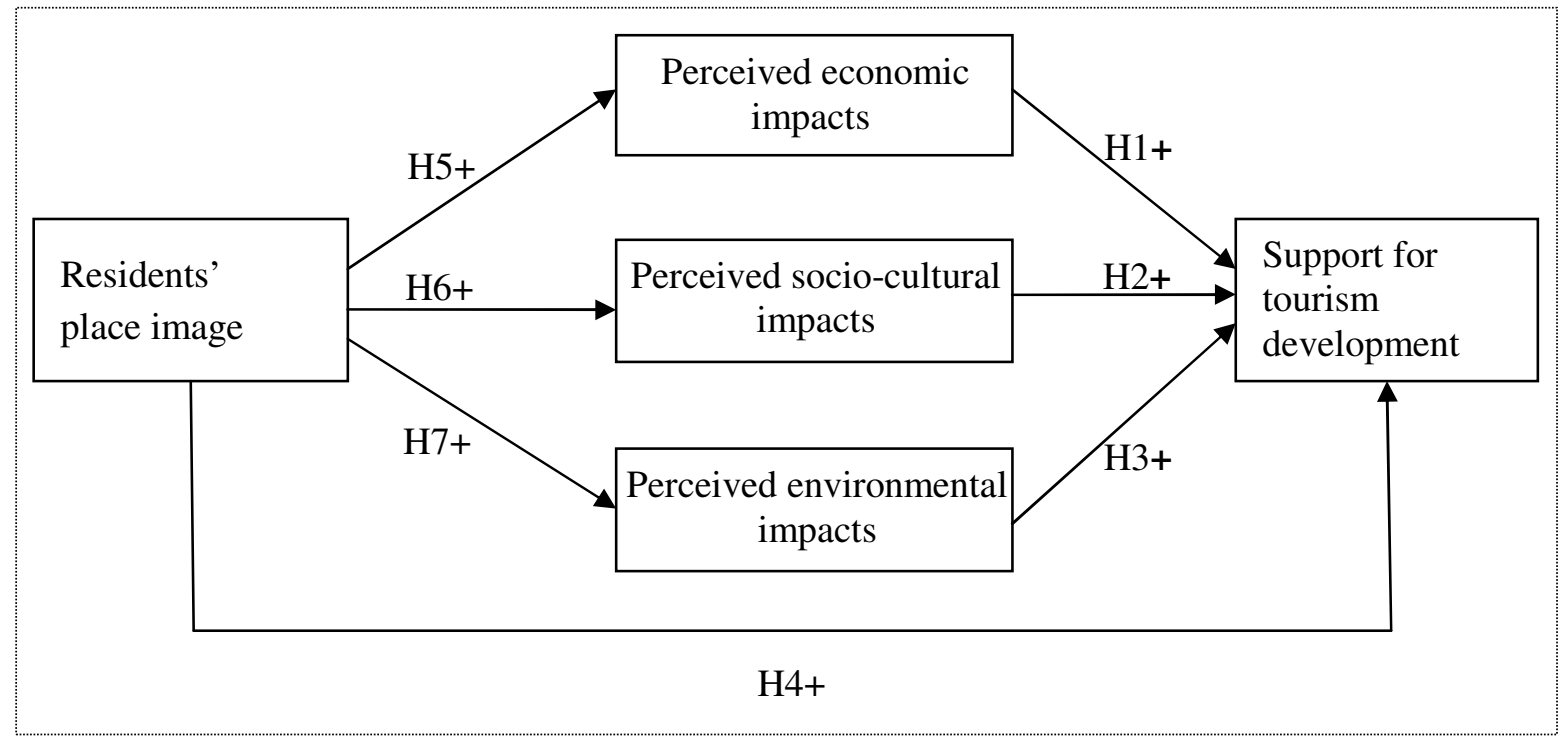




\begin{tabular}{|c|c|c|c|c|}
\hline & Mean & $\begin{array}{c}\text { Std. } \\
\text { Deviation }\end{array}$ & Skewness & Kurtosis \\
\hline Residents'place image & 3.29 & & & \\
\hline Attractive scenery & 4.46 & 0.80 & -1.67 & 2.80 \\
\hline Pleasant weather & 3.95 & 1.04 & -0.89 & 0.23 \\
\hline Safe place to live & 3.85 & 0.98 & -0.78 & 0.41 \\
\hline Interesting historic sites & 3.57 & 1.07 & -0.50 & -0.24 \\
\hline Good restaurants/food & 3.59 & 1.04 & -0.60 & -0.08 \\
\hline Clean & 3.55 & 1.05 & -0.47 & -0.29 \\
\hline Nice architecture & 3.40 & 1.13 & -0.43 & -0.48 \\
\hline $\begin{array}{l}\text { Effective public services (fire, police, } \\
\text { etc.) }\end{array}$ & 3.08 & 1.07 & -0.18 & -0.42 \\
\hline Friendly locals & 2.97 & 1.22 & -0.15 & -0.91 \\
\hline Good public transportation system & 2.86 & 1.27 & 0.03 & -1.03 \\
\hline Good place for shopping & 2.74 & 1.25 & 0.15 & -0.97 \\
\hline Effective local government & 2.64 & 1.07 & 0.06 & -0.68 \\
\hline Good nightlife/ entertainment & 2.56 & 1.23 & 0.28 & -0.97 \\
\hline Good job opportunities & 2.17 & 1.10 & 0.49 & -0.76 \\
\hline Economic impacts & 3.40 & & & \\
\hline Revenue generated in the local economy & 3.73 & 1.03 & -0.59 & -0.25 \\
\hline Standard of living & 3.60 & 0.94 & -0.44 & -0.23 \\
\hline Number of jobs & 3.51 & 1.12 & -0.40 & -0.65 \\
\hline Infrastructure & 3.51 & 1.09 & -0.53 & -0.39 \\
\hline Price of land/housing & 2.67 & 1.13 & 0.37 & -0.66 \\
\hline Socio-cultural impacts & 3.41 & & & \\
\hline $\begin{array}{l}\text { Opportunity to meet people from other } \\
\text { cultures }\end{array}$ & 3.74 & 1.09 & -0.83 & 0.23 \\
\hline Cultural actives /entertainment & 3.51 & 1.17 & -0.63 & -0.41 \\
\hline Availability of recreational facilities & 3.42 & 1.10 & -0.45 & -0.51 \\
\hline Quality of public services (fire, police) & 3.24 & 1.01 & -0.41 & -0.04 \\
\hline Community spirit & 3.12 & 1.03 & -0.18 & -0.25 \\
\hline Crime level & 2.81 & 0.94 & 0.09 & -0.24 \\
\hline Environmental impacts & 2.63 & & & \\
\hline Noise levels & 2.82 & 0.94 & 0.02 & -0.16 \\
\hline Environmental pollution & 2.61 & 1.00 & 0.40 & -0.19 \\
\hline Crowding & 2.61 & 1.05 & 0.32 & -0.48 \\
\hline Traffic congestions & 2.48 & 1.17 & 0.51 & -0.53 \\
\hline Support for tourism development & 3.92 & & & \\
\hline Further tourism development & 4.04 & 1.13 & -1.04 & 0.19 \\
\hline Public funding for tourism promotion & 3.91 & 1.24 & -0.86 & -0.38 \\
\hline Increase in the volume of tourists & 3.83 & 1.27 & -0.79 & -0.52 \\
\hline
\end{tabular}

